\title{
Prevalence of sleep apnoea in patients with chronic kidney disease (CKD) receiving renal replacement therapy by haemodialysis
}

\author{
Ilona Miśḱowiec-Wiśniewska', Rafał Donderski', Jacek J. Klawe'², Jacek Manitius' \\ ${ }^{1}$ Department of Nephrology, Hypertension and Internal Diseases of the Nicolaus Copernicus University Collegium Medicum in Bydgoszcz \\ ${ }^{2}$ Department of Hygiene, Epidemiology and Ergonomics of the Nicolaus Copernicus University Collegium Medicum in Bydgoszcz
}

\section{Abstract}

Background. Sleep disorders in kidney disease patients occur more frequently than in the general population. Chronic renal disease patients are commonly diagnosed with sleep apnoea syndrome. It occurs in the obstructive, central and mixed form and is of multicausal nature. The aim of the present paper was to assess the frequency of individual types of sleep-related breathing disorders in chronically haemodialysed patients using polysomnography. Material and methods. The study involved stage $5 \mathrm{CKD}$ patients receiving continuous renal replacement therapy by haemodialysis.

Results. The obtained results suggest that weight gain between consecutive haemodialysis sessions correlates with more frequent occurrences of disordered breathing events (apnoeas and hypopnoeas) in patients on the night preceding haemodialysis session.

Conclusions. Positive linear correlations are observed of systolic and diastolic BP measured before PSG performed on the day before a haemodialysis session with the number of snoring episodes, which might suggest that breathing disorders affect the complex pathogenesis of hypertension in haemodialysed patients.

key words: sleep, sleep apnoea, arterial hypertension, chronic kidney disease, haemodialysis therapy

Arterial Hypertens. 2016, vol. 20, no. 2, pages: 44-50

DOI: $10.5603 / A H .2016 .0008$

\section{Introduction}

Sleep constitutes a very important part of human life. It usually takes up a fourth, and in some cases even a third of a person's life. Sleep requirements vary between individuals. Research studies suggest that sleep deprivation, i.e. sleeping less than 6 hours a night, or excessive sleep, i.e. sleeping more than 9 hours a night, correlates with an increased risk of premature death. Many researchers have stressed the significance of sleep in human life. It is needed to restore the efficiency of the organism, allows economising on limited energy resources and provides protec- tion against excessive stress [1-4]. During sleep, the supply of energy-rich phosphates becomes restored, the synthesis of proteins and neurotransmitters improves, and cell division processes accelerate $[3,4]$.

Sleep disorders in patients with kidney disease are more frequent than in the general population. Merlino et al. observed the occurrence of such disorders in about $80 \%$ out of 883 investigated patients receiving haemodialysis (HD) treatment. The most common types of sleep disorders were: insomnia (69\% of patients), restless legs syndrome $(18 \%)$, obstructive sleep apnoea syndrome $(24 \%)$, and excessive daytime sleepiness (12\%) [5]. From among

\footnotetext{
Address for correspondence: llona Małgorzata Miśkowiec-Wiśniewska Katedra i Klinika Nefrologii, Nadciśnienia Tętniczego i Chorób Wewnętrznych, Uniwersytet im. M. Kopernika w Toruniu, Collegium Medicum im. L. Rydygiera w Bydgoszczy, Szpital Uniwersytecki nr 1 w Bydgoszczy ul. M. Skłodowskiej-Curie 9, 85-096 Bydgoszcz tel.: (052) 585-40-30, 585-45-29, fax: (052) 585-40-30 e-mail: ilonamis@wp.pl
} 
the above conditions, the sleep apnoea syndrome is relatively often diagnosed in patients with chronic kidney disease $(\mathrm{CKD})$. It occurs in the obstructive, central and mixed form and is of multicausal nature.

Comparing the frequency of occurrence of three main types of sleep-related breathing disorders, that is the obstructive, central and mixed forms of apnoea, stage $5 \mathrm{CKD}$ patients are most often diagnosed with central, and only slightly less frequently with the obstructive form of apnoea [15].

Sabatini et al. confirmed the increased prevalence of sleep disorders in haemodialysed patients [16]. The finding applied to patients receiving dialysis treatment in the mornings for over 12 months and with increased PTH levels. Disorders observed most frequently were: frequent nighttime awakenings (92\% of cases), difficulty falling asleep (67\%), and early-morning awakenings (62\%).

The most significant of the consequences of sleep-related breathing disorders are cardiovascular complications. Conditions occurring more frequently in this group of patients are: resistant hypertension, left ventricular hypertrophy, ischaemic heart disease, and malignant arrhythmia. Higher prevalence of myocardial infarction and stroke has also been observed [17-19]. Extreme cases of sleep disorders - excessive daytime sleepiness - lead to an increased number of traffic accidents, which in turn contributes to a further increase in mortality rates.

There have been numerous explanations for the increased prevalence of sleep-related breathing disorders in patients receiving continuous haemodialysis therapy. Significance has been attached to the co-occurrence of atherosclerosis and diabetes, and partly to the presence of such risk factors as the age of over 40 years, male gender, obesity, or arterial hypertension [21]. There are several hypotheses partially explaining the causes of the increased frequency of occurrence of such disorders in patients with end-stage renal disease. One of those has been believed to be metabolic acidosis. However, studies carried out by Kimmel et al. did not find any correlations between metabolic acidosis and apnoea episodes in haemodialysed patients [7, 22].

The significance of anaemia has been considered as another hypothetical factor contributing to the development of sleep apnoea in patients on dialysis. However, research studies conducted by Benz et al. demonstrated that anaemia correction had no impact on the number of apnoeas during sleep [23, 24].

Another causal factor taken into account is the significance of uremic neuropathy and myopathy and the consequent disturbed functioning of respiration muscles [21]. Disorders in neuromuscular transmission caused by uremic toxins aggravate breathing disorders. In the case of effective HD treatment, the clinical symptoms of uremic neuropathy rarely occur, although its subclinical manifestation can be diagnosed in $50 \%$ of cases. This hypothesis might be supported by the fact that a regression of clinical symptoms of uremic neuropathy and a decrease in the number and severity of apnoeas are observed in post-kidney transplant patients [25-27].

\section{Aim of the study}

The aim of the present study was to analyse the frequency of occurrence of different types of sleep-related breathing disorders in patients receiving continuous haemodialysis therapy. The assessment was based on polysomnographic tests performed before and directly after haemodialysis sessions in conjunction with the analysis of biochemical, anthropometric and blood pressure data, as well as their correlations with the frequency of occurrence of breathing disorders during sleep.

\section{Material and methods}

The research study was conducted under permission granted by the Bioethics Committee in the Laboratory of Chronobiology and Chronomedicine of the Department of Human Physiology and the Department of Epidemiology of the Nicolaus Copernicus University Collegium Medicum in Bydgoszcz.

The study involved patients with stage $5 \mathrm{CKD}$, receiving continuous renal replacement therapy by haemodialysis in the Dialysis Centre of the Clinic of Nephrology, Hypertension and Internal Diseases of the University Hospital No. 1 in Bydgoszcz.

The study was carried out in three stages. The first stage consisted in a survey study using the Epworth Sleepiness Scale aimed at identifying patients with the highest risk for sleep-related breathing disorders. The first-stage assessment included 61 patients $(24$ women and 37 men) aged 28 to 78 (mean age $58.2 \pm 12.2$ ) with mean dry weight of $68.16 \pm 13.57 \mathrm{~kg}$, receiving dialysis three times a week for an average of $73.49 \pm 55.33$ months. The mean duration of an HD session was $4.43 \pm 0.43$ hours. The second and third stage of the study involved full polysomnography (PSG) performed on the night directly before and after an HD session using the Alice 3 Diagnostic Sleep System by Respironics. This stage included 17 men, receiving dialysis between 7.00 p.m. and 11.00 p.m. A follow-up PSG test was eventually performed in 11 patients. 6 patients were excluded from the third stage of the study due to: kidney transplantation (1 patient), death (3 patients), withheld consent for a follow-up PSG test (2 patients). 
Table I. Clinical characteristics of patients

\begin{tabular}{|l|c|c|c|c|c|c|c|}
\hline \multirow{2}{*}{ Parameters } & \multicolumn{9}{|c|}{ Clinical characteristics of patients } \\
\cline { 2 - 9 } & Age & BMI & $\begin{array}{c}\text { HD session } \\
\text { duration }\end{array}$ & $\begin{array}{c}\text { HD duration } \\
\text { (months) }\end{array}$ & Dry weight & $\begin{array}{c}\text { Weight gain } \\
\text { between HD }\end{array}$ & Hours of sleep \\
\hline Min & 28 & 15.00 & 3.50 & 7.00 & 38.00 & 1.00 & 2.00 \\
\hline Max & 78 & 36.00 & 5.50 & 236.00 & 98.50 & 4.30 & 10.00 \\
\hline Median & 58.0 & 24.00 & 4.50 & 58.00 & 66.00 & 2.50 & 6.25 \\
\hline Mean & 58.2 & 23.77 & 4.43 & 73.49 & 68.16 & 2.46 & 6.46 \\
\hline SD & 12.2 & 4.11 & 0.43 & 55.53 & 13.57 & 0.70 & 2.05 \\
\hline
\end{tabular}

Table II. Values of breathing parameters recorded during sleep in patients receiving continuous haemodialysis therapy

\begin{tabular}{|c|c|c|c|c|c|c|c|c|c|c|c|c|}
\hline & \multicolumn{2}{|c|}{$\begin{array}{l}\text { Total number of } \\
\text { apnoeas }\end{array}$} & \multicolumn{2}{|c|}{$\begin{array}{c}\text { Number of central } \\
\text { apnoeas }\end{array}$} & \multicolumn{2}{|c|}{$\begin{array}{c}\text { Number of } \\
\text { obstructive } \\
\text { apnoeas }\end{array}$} & \multicolumn{2}{|c|}{$\begin{array}{c}\text { Number of mixed } \\
\text { apnoeas }\end{array}$} & \multicolumn{2}{|c|}{$\begin{array}{c}\text { Number of } \\
\text { hypopnoeas }\end{array}$} & \multicolumn{2}{|c|}{$\begin{array}{c}\text { Number of snoring } \\
\text { episodes }\end{array}$} \\
\hline & $\begin{array}{l}\text { After } \\
\text { HD }\end{array}$ & $\begin{array}{l}\text { Btwn } \\
\text { HDs }\end{array}$ & $\begin{array}{l}\text { After } \\
\text { HD }\end{array}$ & $\begin{array}{l}\text { Btwn } \\
\text { HDs }\end{array}$ & $\begin{array}{l}\text { After } \\
\text { HD }\end{array}$ & $\begin{array}{l}\text { Btwn } \\
\text { HDs }\end{array}$ & $\begin{array}{l}\text { After } \\
\text { HD }\end{array}$ & $\begin{array}{l}\text { Btwn } \\
\text { HDs }\end{array}$ & $\begin{array}{l}\text { After } \\
\text { HD }\end{array}$ & $\begin{array}{l}\text { Btwn } \\
\text { HDs }\end{array}$ & $\begin{array}{c}\text { After } \\
\text { HD }\end{array}$ & $\begin{array}{l}\text { Btwn } \\
\text { HDs }\end{array}$ \\
\hline $\mathrm{n}$ & 17 & 11 & 17 & 11 & 17 & 11 & 17 & 11 & 17 & 11 & 17 & 11 \\
\hline Min & 1 & 2 & 0 & 0 & 0 & 0 & 0 & 0 & 1 & 1 & 0 & 0 \\
\hline Max & 142 & 354 & 127 & 119 & 110 & 194 & 29 & 41 & 79 & 172 & 255 & 284 \\
\hline Median & 37.0 & 43.0 & 21.0 & 13.0 & 5.0 & 13.0 & 2.0 & 1.0 & 34.0 & 63.0 & 20.0 & 52.0 \\
\hline Mean & 56.9 & 68.6 & 27.7 & 27.7 & 19.1 & 33.0 & 4.2 & 7.9 & 31.6 & 62.1 & 37.3 & 71.7 \\
\hline SD & 45.9 & 102.2 & 31.9 & 39.5 & 29.0 & 55.7 & 7.3 & 12.7 & 23.3 & 54.6 & 60.3 & 94.5 \\
\hline
\end{tabular}

Table III. Index of breathing events per one hour of recorded sleep

\begin{tabular}{|c|c|c|c|c|c|c|c|c|c|c|}
\hline & \multicolumn{2}{|c|}{$\begin{array}{l}\text { Index of breathing } \\
\text { events per } 1 \text { hour of } \\
\text { sleep }\end{array}$} & \multicolumn{2}{|c|}{$\begin{array}{c}\text { Index of central } \\
\text { apnoeas per } 1 \text { hour of } \\
\text { sleep }\end{array}$} & \multicolumn{2}{|c|}{$\begin{array}{l}\text { Index of obstructive } \\
\text { apnoeas per } 1 \text { hour of } \\
\text { sleep }\end{array}$} & \multicolumn{2}{|c|}{$\begin{array}{c}\text { Index of mixed } \\
\text { apnoeas per } 1 \text { hour of } \\
\text { sleep }\end{array}$} & \multicolumn{2}{|c|}{$\begin{array}{l}\text { Index of hypopnoeas } \\
\text { per } 1 \text { hour of sleep }\end{array}$} \\
\hline & $\begin{array}{c}\text { After } \\
\text { HD }\end{array}$ & Btwn HDs & $\begin{array}{c}\text { After } \\
\text { HD }\end{array}$ & Btwn HDs & $\begin{array}{c}\text { After } \\
\text { HD }\end{array}$ & Btwn HDs & $\begin{array}{c}\text { After } \\
\text { HD }\end{array}$ & Btwn HDs & $\begin{array}{c}\text { After } \\
\text { HD }\end{array}$ & Btwn HDs \\
\hline $\mathrm{n}$ & 17 & 11 & 17 & 11 & 17 & 11 & 17 & 11 & 17 & 11 \\
\hline Min & 0.9 & 0.9 & 0 & 0 & 0 & 0 & 0 & 0 & 0.1 & 0.1 \\
\hline Max & 35.2 & 45.4 & 22.1 & 15 & 18.8 & 16.8 & 5.4 & 3.5 & 15 & 17.3 \\
\hline Median & 15.6 & 17.1 & 4.5 & 2.1 & 1.9 & 1.7 & 0.3 & 0.2 & 7.7 & 10.4 \\
\hline Mean & 17.9 & 17.4 & 5.9 & 3.9 & 3.8 & 3.9 & 1.1 & 1.0 & 7.0 & 8.6 \\
\hline SD & 12.0 & 14.0 & 6.0 & 4.8 & 5.1 & 5.0 & 1.8 & 1.4 & 4.6 & 6.0 \\
\hline
\end{tabular}

Table I presents the clinical characteristics of patients participating in the study — qualified for the first stage.

\section{Results}

Table II presents the values of breathing parameters recorded during sleep in patients receiving continuous haemodialysis. During the performed polysomnography, the highest number of breathing events was observed between HDs - a total of 208.4 breathing events was observed, including a total of
$68.6 \pm 102.2$ apnoeas (including: $27.7 \pm 39.5$ central apnoeas, $33 \pm 55.7$ obstructive apnoeas, and $7.9 \pm$ 12.7 mixed apnoeas), $62.1 \pm 54.6$ hypopnoeas, and $77.7 \pm 94.5$ snoring episodes.

Table III presents the index of breathing events recorded during sleep.

Statistically significant linear correlations were found between BMI and the number of central apnoeas in the group of patients examined between HD sessions (btwn HDs), and between BMI and the number of central apnoeas in the group of patients after HD sessions (after HD) (Table IV). 
Table IV. Values of linear correlation coefficients between BMI and the number of central and mixed apnoeas

\begin{tabular}{|l|c|c|c|c|c|}
\hline \multirow{2}{*}{} & $\mathbf{n}$ & \multicolumn{2}{|c|}{ Btwn HDs } & \multicolumn{2}{c|}{ After HD } \\
\cline { 3 - 6 } & & $\begin{array}{c}\mathbf{R} \\
\text { Spearman }\end{array}$ & $\mathbf{p}$ & $\begin{array}{c}\mathbf{R} \\
\text { Spearman }\end{array}$ & $\mathbf{p}$ \\
\hline BMI \& total number of apnoeas & & $\mathbf{0 . 6 4}$ & $\mathbf{0 . 0 4 7 9}$ & 0.53 & 0.1173 \\
\hline BMI \& total number of hypopnoeas & 10 & 0.43 & 0.2202 & 0.52 & 0.1276 \\
\hline BMI \& number of central apnoeas & 10 & $\mathbf{0 . 5 9}$ & $\mathbf{0 . 0 7 1 7}$ & $\mathbf{0 . 8 3}$ & $\mathbf{0 . 0 0 2 9}$ \\
\hline BMI \& number of obstructive apnoeas & 10 & 0.30 & 0.4032 & 0.10 & 0.7770 \\
\hline BMI \& number of mixed apnoeas & 10 & $\mathbf{0 . 5 6}$ & $\mathbf{0 . 0 9 4 8}$ & $\mathbf{0 . 6 6}$ & $\mathbf{0 . 0 3 6 0}$ \\
\hline BMI \& number of snoring episodes & 10 & -0.05 & 0.8810 & 0.16 & 0.6515 \\
\hline BMI \& systolic BP & 10 & -0.17 & 0.6372 & 0.04 & 0.9059 \\
\hline BMI \& diastolic BP & 10 & -0.21 & 0.5541 & -0.02 & 0.9587 \\
\hline
\end{tabular}

Table V. Linear correlations between body weight gain and the number of breathing events

\begin{tabular}{|l|c|c|c|}
\hline & $\mathbf{n}$ & R Spearman & p-value \\
\hline$\Delta$ body weight btwn HDs \& total number of apnoeas btwn HDs & 10 & $\mathbf{0 . 6 0}$ & $\mathbf{0 . 0 6 6 7}$ \\
\hline$\Delta$ body weight btwn HDs \& total number of hypopnoeas btwn HDs & 10 & $\mathbf{0 . 5 7}$ & $\mathbf{0 . 0 8 4 4}$ \\
\hline$\Delta$ body weight btwn HDs \& number of central apnoeas btwn HDs & 10 & $\mathbf{0 . 5 6}$ & $\mathbf{0 . 0 9 1 6}$ \\
\hline$\Delta$ body weight btwn HDs \& number of obstructive apnoeas btwn HDs & 10 & 0.30 & 0.3932 \\
\hline$\Delta$ body weight btwn HDs \& number of mixed apnoeas btwn HDs & 10 & $\mathbf{0 . 5 6}$ & $\mathbf{0 . 0 9 4 8}$ \\
\hline$\Delta$ body weight btwn HDs \& number of snoring episodes btwn HDs & 10 & 0.27 & 0.4458 \\
\hline
\end{tabular}

Positive correlations were found between body weight gain ( $\Delta$ body weight) between HDs and the total number of apnoeas between HDs, and between body weight gain ( $\triangle$ body weight) and the number of mixed apnoeas and hypopnoeas (Table V).

Positive linear correlations were found between systolic and diastolic BP measured before PSG performed on the day prior to the next HD session and the number of snoring episodes.

\section{Discussion}

Sleep-related breathing disorders constitute a major clinical problem in the general population and in the population of patients with $\mathrm{CKD}$ receiving both conservative and renal replacement treatment.

In Poland, there is still no epidemiological data on the matter. There has not yet been any detailed explanation of the causes responsible for the increased prevalence of sleep apnoea syndromes in patients suffering from kidney diseases. One of the many factors considered to play a significant role in the occurrence of sleep apnoea in the said population of patients is the effect of uremic toxins, metabolic acidosis and overhydration on the mechanisms of breathing regulation. The impact of anaemia on the increased frequency of sleep apnoea has also been taken into account; however, it has been demonstrated that improving the levels of haemoglobin and haematocrit has no significant effect on decreasing the number of apnoeas during sleep in patients treated with continuous haemodialysis $[8,23,24,28]$. A decisive role in identifying the sleep apnoea syndrome is played by polysomnography. It allows determining the frequency of occurrence and type of breathing disorders with the greatest accuracy. According to the results of recent studies, the prevalence of sleep apnoea syndromes in CKD patients is ten times higher than in the general population. Over $50 \%(53-75 \%$ as reported by different sources) of patients are diagnosed with sleep-related breathing disorders $[6-8,29]$ and approximately $54-80 \%$ of patients suffer from at least one type of sleep disorder. It has also been found that the frequency of occurrence of sleep apnoea is similar between the group of CKD patients receiving conservative treatment and the group of patients receiving renal replacement therapy $[29,30]$. The type of dialysis treatment (peritoneal dialysis vs haemodialysis) is of no real significance in reducing the number of apnoeas during sleep [8]. Changing the form of treatment from conventional haemodialysis (intermittent HD sessions) to nocturnal haemodialysis administered for 6-7 nights a week decreases the 
frequency and severity of sleep apnoeas and improves the quality of life of patients [31,32].

PSG tests performed in the present study determined a quantitative prevalence of central apnoeas over obstructive ones, although the difference was of no statistical significance. Similar findings were reported by Kimmel et al. [7]. In a study by Yeh et al., 62\% of patients had mixed apnoea, while the remaining 38\% had obstructive apnoea [42]. In a study by Rodriguez et al., $31.1 \%$ out of 45 examined patients had $\mathrm{AHI} \geq 5$; the obstructive type of apnoea was prevalent in those patients [43]. In patients with CKD, central and obstructive apnoeas are mainly observed.

In the present study, an attempt was made to assess the effect of an HD session on the frequency of occurrence of breathing disorders. The number of disordered breathing events was higher on the night before an HD session, although no statistical significance was determined. A statistically significant lower number of hypopnoeas was observed during PSG performed directly after an HD session.

Moreover, positive correlations were found between body weight gain ( $\Delta$ weight) between HDs and the total number of apnoeas between HDs, and between body weight gain ( $\Delta$ weight) and the number of mixed apnoeas and hypopnoeas between HDs.

Although the present study found no statistically significant difference between the aggravation of metabolic acidosis and the frequency of disordered breathing events, a decrease in the number of hypopnoeas observed in PSG tests after HD sessions suggests that controlling metabolic acidosis and electrolyte imbalance, as well as reducing the concentration of uremic toxins in plasma, might exert a positive effect on decreasing the number of disordered breathing events. The occurrence of an increased number of central apnoeas during PSG between HDs indicates a possible depressive effect of such biochemical factors as metabolic acidosis and uremic toxins on the respiratory centre. Nevertheless, no correlations were found between acidosis and the number of disordered breathing events. It may thus be only tentatively concluded that a haemodialysis session has a positive impact on the improvement of breathing disorders during sleep in patients receiving continuous haemodialysis treatment. Due to the too limited size of the study group and the diverse pathophysiological mechanism of sleep apnoea in patients suffering from chronic renal disease, it is difficult to assess the true impact of HD treatments on the sleep apnoea syndrome.
Arterial hypertension is a significant risk factor for cardiovascular complications in haemodialysed patients [46]. Epidemiological studies have indicated that patients with obstructive sleep apnoea have increased arterial blood pressure [47-50]. This applies to both the general population and the population of kidney disease patients.

Sleep apnoeas lead to an increase in systolic and diastolic blood pressure by about 25-30\% [4]. It is caused by the increased activation of chemoreceptors in response to the developing hypoxaemia and hypercapnia $[4,52]$. Furthermore, a significant role in the development of hypertension in sleep apnoea patients is played by a decreased reactivity of arterial baroreceptors, an increased activity of the sympathetic nervous system, the effect of hormonal factors (catecholamines), and the stimulation of the renin-angiotensin-aldosterone system [51, 52]. In the present study, positive linear correlations were found between the values of systolic and diastolic BP measured before PSG performed on the day prior to the next haemodialysis session and the number of snoring episodes. The observed finding might have been caused by the aggravating symptoms of overhydration with concurrent metabolic disorders leading to the obstruction of the upper airway - an oedematous component within the nasopharynx. What is more, the increased frequency of central apnoeas was most likely caused by metabolic disorders intensifying due to the interval between haemodialysis sessions. The observations on arterial hypertension made in the present study confirm the findings of Rodriguez et al. [43], whereas Kuhlman et al. found no statistically significant differences in arterial hypertension between patients with and without sleep apnoea [28]. The discrepancies in results might be due to the inhomogeneity of study groups. It is difficult to determine the exact nature of arterial hypertension in patients suffering from sleep apnoea. Davies et al. determined an increase in systolic pressure and a slight decrease in diastolic pressure at night compared to measurements taken during the day [52]. In studies carried out by Grote et al., the most common type of hypertension in sleep apnoea patients was systolic-diastolic hypertension.

\section{Additional comments}

The values of the obtained results might have been affected by the too limited size of the study group resulting from the unwillingness of patients to participate in polysomnography tests. The same issue has been addressed by other authors working on similar research problems. The majority of patients who participated in the first stage of the present study, i.e. in 
the questionnaire survey, withdrew from participating in the further stage upon being instructed in the course of the examination. For this reason, 17 men went on to take part in the second stage and only 11 in the third stage of the study.

\section{Conclusions}

On the basis of the results of the present study it might be concluded that body weight gain between haemodialysis sessions correlated with an increased number of disordered breathing events (apnoeas and hypopnoeas) observed in patients during the night before an HD session. Moreover, positive linear correlations have been observed between the values of systolic and diastolic BP measured before PSG performed on the day before the next HD session and the number of snoring episodes, which might suggest a possible effect of breathing disorders on the complex pathogenesis of arterial hypertension in haemodialysed patients.

\section{References}

1. Sullivan E.C., Faqi G.I. Obstructive sleep apnoea. Clin. Chest Med. 1985; 6: 4.

2. Szugała-Jurkiewicz B., Hudzik B., Nowak J., Poloński L. Zespół bezdechu we śnie a niewydolność serca. Wiad. Lek. 2004; 57: 161-156.

3. Zieliński J., Koziej M., Mańkowski M. Zaburzenia oddychania w czasie snu. Wydawnictwo Lekarskie PZWL 1996.

4. Zieliński J., Cieśliński J.K., Koziej M., Mańkowski M. Zaburzenia oddychania w czasie snu. Biblioteka Kształcenia Podyplomowego Instytutu Gruźlicy i Chorób Płuc, Warszawa, t. VIII.

5. Merlino G.,Piani A.,Dolso P. et al. Sleep disorders in patients with end-stage renal disease undergoing dialysis therapy. Nephrol. Dial. Transplant. 2006; 21: 184-190.

6. Hanly P. Sleep apnoea and daytime sleepiness in End-Stage Renal Disease. Seminars in Dialysis 2004; 17: 109-114.

7. Kimmel P.L., Miller G. Sleep apnoea syndrome in chronic renal disease. Am. J. Med. 1989; 86: 308-314.

8. Wadhwa N.K., Selinger M., Greenberg H.E. et al. Sleep related respiratory disorders in end-stage renal disease patients on peritoneal dialysis. Peritoneal Dialysis International 1991; 12: 51-56.

9. Hosselet J.-J., Ayappa I., Norman R.G. et al. Classification of sleep-disordered breathing. Am. J. Resp. Crit. Care Med. 2001; 163: 398-405.

10. Chervin R.D. Sleepiness, fatigue, tiredness and lack of energy in obstructive sleep apnoea. Chest 2000; 118: 372-379.

11. Duran J., Esnaola S., Rubio R., Iztueta A. Obstructive sleep apnoea-hypopnoea and related clinical features in a population-based sample of subjects aged 30 to $70 \mathrm{yr}$. Am. J. Resp. Crit. Care Med. 2001; 163: 685-689.

12. Kapsimalis F., Kryger M.H. Sleep-related breathing disorders. Gender and obstructive sleep apnoea syndrome, part 1: Clinical Features. Sleep 2002; 25: 409-416.

13. Young T., Pepard P.E., Gottlieb D.J. Epidemiology of obstructive sleep apnoea. A population health perspective. Am. J. Resp. Crit. Care Med. 2002; 16: 1217-1239.

14. Young T., Palta M., Demsey J. et al. The occurrence of sleep-disordered breathing among middle-aded adults. N. Engl. J. Med. 1993; 328: 1230-1235.

15. Lin T.S., Yeh J.Ch., Chen H.H. et al. Dialysis effect on obstructive sleep apnoea syndrome in uremic patients. Acta Nephrologica 1997; Vol 11, No 1.
16. Sabbatini M., Minale B., Crispo A. et al. Insomnia in maintenance haemodyalisis patients. Nefrol. Dial. Transplant. 2002; 17: 852-857.

17. De Oliveira Rodrigues C.J., Marson O., Tufic S. et al. Relationship among end-stage renal disease, hypertension, and sleep apnoea in nondiabetic dialysis patients. Am. J. Hypertens. 2005; 18: 152-157.

18. Jung H.H., Han H. Lee J.H. Sleep apnoea, coronary artery disease and antioxidant status in haemodialysis patients. Am. J. Kidney Dis. 2005; 45: 875-882.

19. Zoccali C. Sleep apnoea and nocturnal hypoxemia in dialysis in dialysis patients: mere risk-indicators or causal factors for cardiovascular disease? Nephrol. Dial. Transplant. 2000; 15: 1919-1921.

20. Benz R.L., Pressman M.R., Hivick E.T. et al. Potential novel predictors of mortality in end-stage renal disease patients with sleep disorders. Am. J. Kidney Dis. 2000; 35: 1052-1060.

21. Zoccali C., Mallamaci F., Tripepi G. Sleep apnoea in renal patients. J. Am. Soc. Nephrol. 2001; 12: 2854-2859.

22. Kimmel P.L., Gavin Ch., Miller G. et al. Disordered sleep and noncompliance in a patients with end-stage renal disease. Adv. Ren. Replace Ther. 1997; 4: 55-67.

23. Benz R.L., Pressman M.R., Hivick E.T. et al. A preliminary study of the effects of correction of anaemia with recombinant human erythropoietin therapy on sleep, sleep disorders, and daytime sleepiness in haemodialysis patients.(The SLEEPO study). Am. J. Kidney Dis. 1999; 34: 1089-1095.

24. Winnicki M., Shamsuzzaman A., Lafranchi P. et al. Erythopoetin and obstructive sleep apnoea. Am. J. Hypertens. 2004; 17: 783-786.

25. Aukley D.H, Schmidt-Nowara W., Brown L.K. Reversal of sleep hypopnoea syndrome in End-Stage Renal Disease after kidney transplantation. Am. J. Kidney Dis. 1999; 34: 739.

26. Hanly P., Pierratos A. Improvement of sleep apnoea in patient with chronic renal failure who undergo nocturnal haemodialysis. N. Engl. J. Med. 2001; 344: 102-107.

27. Sabbatini M., Crispo A., Pisani A. et al. Sleep quality in renal transplant patients: a never investigated problem. Nephrol. Dial. Transplant. 2005; 20: 194-198.

28. Kuhlmann U., Becker H.F., Birkhahn M et al. Sleep-apnoea in patients with end-stage renal diseases and objective results. Clin. Nephrol. 2000; 53: 460.

29. Markou N., Kanakaki M., Myrianthefs P. et al. Sleep-disordered breathing in nondialysed patients with chronic renal failure. Lung 2006; 184: 43-49.

30. Merlino G., Piani A., Dolso P. et al. Sleep disorders in patients with end-stage renal disease undergoing dialysis therapy. Nephrol. Dial. Transplant. 2006; 21: 184-190.

31. Bearpark H. Snoring and sleep apnoea. A population study in Australian men. Am. J. Respir. Crit. Care Med. 1995; 151: 1459-1465.

32. Wetter T.C., Bohm G.B. Improvement of sleep apnoea in patients with chronic renal failure who undergo nocturnal haemodialysis. Sleep Med. 2001; 2: 463-465.

33. Hopkins K. Faciliting sleep for patients with end-stage renal disease. Nephrol. Nurs. J. 2005; 32: 189-195.

34. Iliescu E.A., Yeates K.E., Holland D.C. Quality of sleep in patients with chronic kidney disease. Nephrol. Dial. Transplant. 2004; 19: 95-99.

35. Novak M., Shapiro C.M., Mendelssohn D. et al. Diagnosis and management of insomnia in dialysis patients. Semin. Dial. 2006; 19: 25-31.

36. Parker K.P., Bliwise D.L., Rye D. Excessive daytime sleepiness and functioning in dialysis patients. Semin. Dial. 1999; 12: 311-316.

37. Erten Y., Kokturk O., Yuksel A. et al. Relationship between sleep complains and proinflamatory cytokine in haemodialysis patients. Nephrology 2005; 10: 330-335.

38. Peppard P.E., Young T., Palta M. et al. Prospective study of association between sleep-disordered breathing and hypertension. N. Engl. J. Med. 2000; 342: 1378-1384.

39. Chervin R.D., Aldrich M.S., Pickett R., Guilleminault C. Comparison of the results of the Epworth sleepiness scale and multiple sleep latency test. J. Psychosom. Res. 1997; 42: 145-155.

40. Jonczak L., Bednarek M., Pływaczewski R. et al. Porównanie wyników kwestionariusza zaburzeń oddychania w czasie snu w populacji dorosłych mieszkańców Warszawy. Pneumonol. Alergol. Pol. 2003; 3-4: 164-167. 
41. Zieliński J., Polakowska M., Kurjata P. et al. Nadmierna senność dzienna wśród dorosłych mieszkańców Warszawy. Arch. Med. Wewn. 1998; 99: 407-413.

42. Yeh J.C., Lee K.T. The relationship between chronic renal failure and sleep apnoea syndrome. J. Nephro. ROC 1994; 8: 232-237.

43. Rodriguez M.A., Merino D., Grizzo M. et al. Sleep disorders in haemodialysis patients. Transplantation Proceedings 1999; 31: 3082-3086.

44. Sanner B.R., Tewpel M., Esser M. et al. Sleep-related breathing disorders impair quality of life in haemodyalisis recipients. Nefrol. Dial. Transplant. 2002; 17: 1260-1265.

45. Fein A.M. Reversal of sleep apnoea in uremia by dialysis. Arch. Int. Med. 1987; 147: 1355-1356.

46. Ezzati M., Lopez A.D., Rodgers A. et al. Comparative Risk assessment Collaborating Group. Selected major risk factors and global and regional burden of disease. Lancet 2002; 360: 1347-1360.

47. Gami A.S., Pressman G., Caples S.M. et al. Association of arterial fibrillation and obstructive sleep apnoea. Circulation 2004; 110: 364-367.
48. Guilleminault C., Connolly S.J., Winkle R.A. Cardiac arrhythmia and conduction disturbances during sleep in 400 patients with sleep apnoea syndrome. Am. J. Cardiol. 1983; 52: 490-494.

49. Mehra R., Benjamin E.J., Sahar E. et al. Association of nocturnal arrhythmias with sleep-disordered breathing. The sleep heart health study. Am. J. Resp. Crit. Care Med. 2006; 173: 910-916.

50. Ohayon M.M., Guilleminault C., Priest R.G. et al. Is sleep-disordered breathing an independent risk factor for hypertension in general population? J. Psychosom. Res. 2000; 48: 593-601.

51. Gaciong Z., Wolf J., Narkiewicz Z. Obturacyjny bezdech senny i nadciśnienie tetnicze. Pneumonol. Alergol. Pol. 2007; 75 (supl. 1): 57-61.

52. Myśliński W., Dybała A., Mosiewicz J., Prystupa A., Hanzlik J. Zaburzenia czynności układu sercowo-naczyniowego u chorych z zespołem obturacyjnego bezdechu sennego. Wiad. Lek. 2005; 58: 78-83. 